\title{
Building Information Modelling (BIM) and Project Management: a Stakeholders Perspective
}

Agnese Travaglini

Department of Management,

Economics and Industrial Engineering, Politecnico di Milano

agnese.travaglini@mail.polimi.it
Mladen Radujković

Faculty of Civil Engineering,

University of Zagreb

mladen@grad.hr
Mauro Mancini

Department of Management,

Economics and Industrial Engineering,

Politecnico di Milano

mauro.mancini@polimi.it
DOI 10.5592/otmcj.2014.2.8

Research paper

\section{Keywords}

Building Information Modelling (BIM), Project management, Stakeholder, Government
CONSTRUCTION PROJECTS ARE BECOMING MUCH MORE COMPLEX AND DIFFICULT TO MANAGE. AS A RESPONSE INFORMATION AND

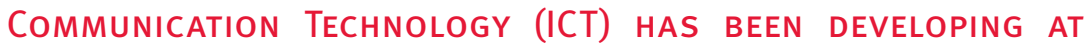
A VERY FAST PACE. The major shift in ICT for the Architecture Engineering and Construction (AEC) sector is the spreading of Building Information Modeling (BIM) (Bryde, Broquetas, \& Volm, 2013). BIM is a system and its main objective is the managing of the information and because of that it is also a project management matter. Our research work is originated from the understanding of the managerial relationship gap between the two realities of BIM and project management. In particular this paper aims at addressing this gap from a specific perspective: stakeholders. Stakeholder management is one of the most important project critical success factors, as project success highly depends on stakeholders' satisfaction. The goal is relevant for both practitioners and educators. The exploration is done mainly through the literature review, but it is also strongly supported by the collection of primary data. The second source regards direct interviews to a portfolio of stakeholders of the AEC industry, e.g. project managers, architects, BIM experts, software resellers, building developer owners, innovation managers. The findings regard the classification of the key stakeholders in BIM adoption and the contextual situation in the different European countries, with particular focus on the role of the Governments. 


\section{INTRODUCTION}

Building Information Modeling (BIM) is defined by the National BIM Standard as a digital representation of a physical and functional characteristic of a facility. As such it serves as a shared knowledge source for information regarding a facility forming a reliable and prompt basis for decision making during its life cycle, defined as existing from earliest conception to demolition phase (NationalBIMStandard, 2014). In fact the objective of BIM is the managing of the information, and so it belongs not only to a design field but also to a project management one. Moreover the managerial relationship between the two realities of BIM and project management exists and it is a two-way direction. To address it, the paper is focused on the stakeholder management perspective.

\section{Literature review}

BIM is a sociotechnical system because it is the combination of man-made technology and the social and institutional consequences of its implementation in the society. It contains associated behaviours, social norms, certain kind of relationships and cultural institutions (WSP, 2013). Its two-way relation with project management is substantial and important. BIM is officially a project management tool and it is demonstrated by at least two realities: first, in the British normative regarding $\mathrm{BIM}$, managerial and informative processes are explicitly cited (NBS, 2013); second, BIM is a project management software, in fact Nemetschek and SAP - two project management software houses - are interested in it (RIB, 2009) (Nemetschek-Allplan, 2014). Moreover SAP called BIM with the expression "Visual PM" to underline the usefulness of the BIM model in the visualization and the understanding for project managers (Cir., 2014).

Profound studies and analysis have been developed regarding the new technology by academics (e.g. (Succar, 2009), (Sebastian, 2011), (Eastman, Teicholz, Sacks, \& Liston, 2008), (Liu, Gao, \& Wang, 2011), (Jianhua \& Hui, 2010)), professional groups (e.g. (NFB, 2012), (NBS, 2013), (NATSPEC, 2013), (McGrawHill, 2010)) and software vendors (e.g. (Autodesk, 2013)), all mostly from a design perspective. Only a very reduced part of the project management literature focuses explicitly on BIM from its own perspective. The exceptions are: an author from a software house, i.e. Allison (2010) who gave ten reasons why project managers should champion 5D BIM software, and two from associations, i.e. Smith (2014) who showed what the benefits for project managers are, and Malone (2014) who affirmed that BIM changes the role of project managers, and, in another paper, claimed the importance of informed project managers (Malone, 2014). The last exception which better underlines the relationship between BIM and project management is an article by Bryde, Broquetas, \& Volm (2013) who analysed the extent to which the use of BIM leads to enhanced benefits to projects and they did it through an analysis of project success criteria structured according to the PMBOK (Project Management Book of Knowledge) knowledge areas (PMI, 2008).

Regarding the BIM literature there are some references to the stakeholders fitting the research purpose. Succar (2009) identified three BIM areas with regards also to the stakeholders. Two other authors Linderoth (2012) and Liu,

\begin{tabular}{|l|l|l|}
\hline \multicolumn{1}{|c|}{ Role } & Nationality & Point of view \\
\hline Professor of University of Osijek (Croatia) & Croatian & Education \\
\hline CEO SME & Italian & Italian market \\
\hline Professor of Politecnico di Milano & Italian & Architecture and construction \\
\hline $\begin{array}{l}\text { Autodesk reseller } \\
\text { Innovation manager of Tridel } \\
\text { (Real estate company) }\end{array}$ & Croatian & BIM software house \\
\hline Professor of Università di Brescia & Canadian & American company leader and innovation \\
\hline Senior project manager & Italian & Government, Italian and European \\
\hline Senior project manager & Croatian & Project manager of complex project \\
\hline CEO micro enterprise & Croatian & Project manager \\
\hline
\end{tabular}

Table 1. Interviewees 


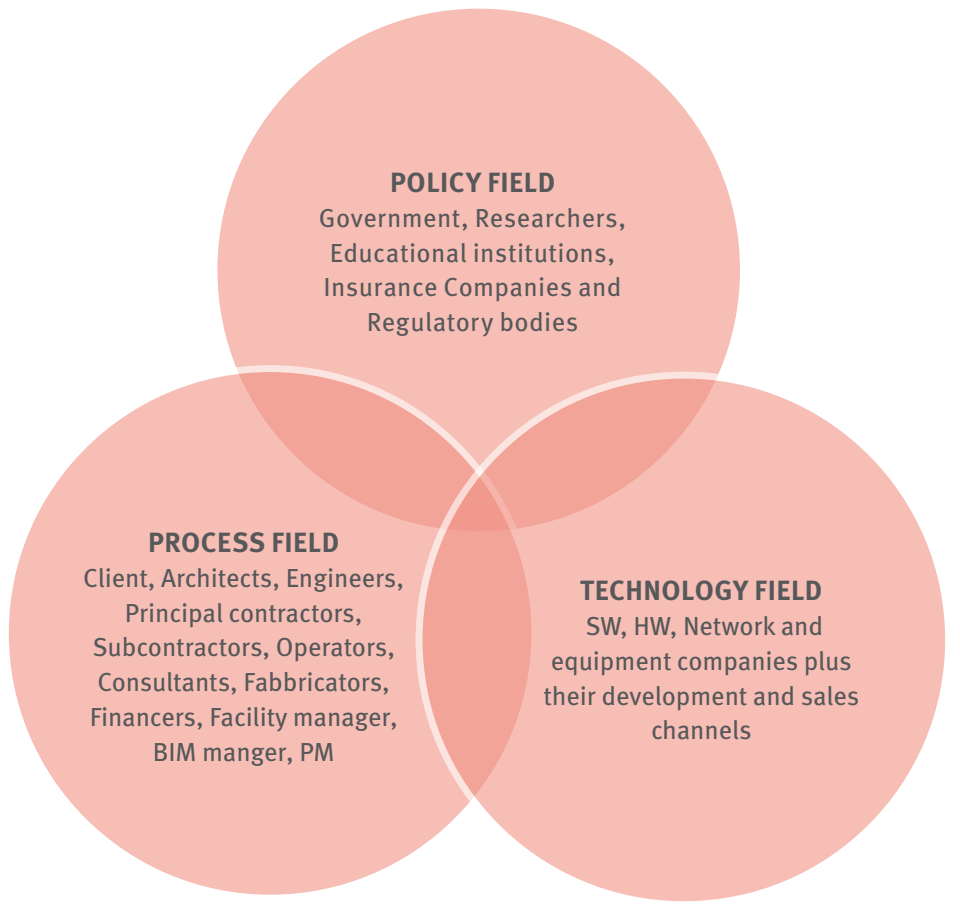

Figure 1. BIM fields (Succar, 2009)

Gao, \& Wang (2011) argued about the power of the stakeholders. Browne, Odeyinka, McKeown \& McNiff (2013) dealed with stakeholders financial benefits, Built Environment Innovationand Industry Council (2010) instead with project ones. Furthers references are about the benefits, the knowldedge and so the interest of the stakeholders, i.e. (Gu \& London, 2010), (Volk, Stenge, \& Schultmann, 2014), (Wong, Wong, \& Nadeem, 2009) and (Eastman, Teicholz, Sacks, \& Liston, 2008).

The secondary data dealing with the particular role of the Governments are numerous and the sources are different, e.g. websites, blogs, surveys, reports, journals. Casa e Clima (2014), Baxter from Autodesk (2013) and Cholakis (2013) gave an overview of the European and also worldwide context situation. Re Cecconi (2014), Autodesk, Temponi \& Malhoaa (2002), Salih (2014) and CIOB, one of the most influential professional body for construction management, were focused on the European Union role. BIM Task Group, MC Gough (2013), Blackwell
(2012), Vukomanović, Radujković \& Dolaček (2012), Rooney from NATSPEC (2014), CIOB (2013), Kiviniemi (2013), and, again, Wong, Wong \& Nadeem (2009) are example of authors who dealed with the situation of specific countries.

\section{Research method}

The paper aims at answering to two main research questions: the first one is about the willingness and the potential of a stakeholder in buying and adopting the BIM system - "Who, among the stakeholders, will buy BIM?" -, and the second is about the specific contexts and so the role of the Governments in the different countries - "What are the Governments doing?". In order to answer to the two issues the research used two different methodologies: literature review and direct interviews. So the sources of the information were both secondary and primary data. The literature was quite rich and so it covered the majority of the information needed, however direct interviews let the integration, the better understanding and strenghthening or weakening some important findings. Mainly 16 secondary data sources were used to answer to the first research question, 15 to the second one.

Direct interviews were addressed to a portfolio of stakeholders of the AEC sector (see table 1), e.g. project managers, architects, BIM experts, software resellers, building developer owners, innovation managers. The context of the research was European with particular focus on the Mediterranean countries, most of the interviewees in fact were Italian or Croatian.

In the interviews they were asked direct questions regarding the stakeholder positioning, and in particular about their interest and power, and about the role of the Governments. The information regarding the first question was much easily collected due to a high knowledge of all the experts about the construction sector, instead the data about the second one could be gathered only from few of them in a complete way, most of them could give only an overview of their country situation.

\section{Results}

The means to answer to the first research question - "Which kind of stakeholder will buy BIM?" - is the stakeholder analysis in order to classify and position the project players. Moreover the best way to assess the problem is to look at it from different perspectives and so using different frameworks.

The first framework analysed (see figure 1) divides the stakeholders according to the three BIM fields: policy field (a policy is the written principles or rule to guide decision-making), process field (a process is a specific ordering of work activities across time and place, with a beginning, an end, and clearly identified inputs and outputs: a structure for action) and technology field (a technology is the application of scientific knowledge for practical purpose) (Succar, 2009). 


\begin{tabular}{|c|c|c|c|}
\hline \multicolumn{2}{|c|}{ Internal stakeholders } & \multicolumn{2}{c|}{ External stakeholders } \\
\hline Demand side & Supply side & Private & Public \\
\hline Client & Architects & Environmentalist & Local authorities \\
\hline Financers & Engineers & Insurance companies & National authorities \\
\hline Principal contractors & Researchers* & Government \\
\hline Subcontractors & Educational institutions* & \\
\hline Operators & Trade and industry & \\
\hline Consultant & Social organizations & \\
\hline Fabricators & Media* \\
\hline Facility manager & \\
\hline BIM manager & \\
\hline PM & \\
\hline Developers & \\
\hline
\end{tabular}

Table 2. Internal and external stakeholders

*It can be both private and public

The second framework (see table 2) differentiates the stakeholders according to their being formally connected with the project - internal - or just being affect by it in some way external. It then divides them according to which side they belong to for the first cluster, and according to their being private or public for the second one. In a construction project is important to identify and understand both the two main groups, but in order to identify the potential buyers the relevant one is only the internal stakeholders (Olander, 2006) (Nash, Chinyio, Gameson, \& Suresh).

The third framework (see figure 2), which resulted to be the most valuable for the research purpose, is the interest and power matrix (Johnson \& Scholes, 1999). In order to answer to the question “Who will buy the new system?" only internal stakeholders are considered.

The matrix classifies the stakeholders in four groups according to two variables: power and interest. The key players (high power and interest) resulted to be, in order: the client (as hypothesis he is identified with the owner), who is the most powerful player and the one gaining more benefits; the project manager, in fact BIM beneficial characteristics let him manage the project in a more efficient and effective way, moreover his role in BIM adoption is crucial because he is the representative of the client and so the direct link and the translator between project and client; the architect, whose project benefits are considerably high; the principal contract, the large (L) ones have twice the interest of the small and medium enterprises (SMEs) (Evans, 2012); and the engineer (both MEP and structural), whose positioning among the key players is the lowest. This classification means that the best candidate to buy and promote BIM is the client because of highest power in the project but also highest interest due to financial and project benefits, which are not always at the client complete awareness. The likely mediator and translator then the project manager due to his positioning and to his linking role in the project. The other three groups are: the players to keep informed (high interest, low power), the players that require minimal effort (low interest and power) and the players to keep satisfied (high power, low interest) (Linderoth, 2012) (Liu, Gao, \& Wang, 2011) (Browne, Odeyinka, McKeown, \& McNiff, 2013) (Built Environment Innovation and Industry Council, 2010) (Gu \& London, 2010) (Volk, Stenge, \& Schultmann, 2014) (Wong, Wong, \& Nadeem,
2009) (Eastman, Teicholz, Sacks, \& Liston, 2008).

Besides the literature review, the direct interviews done in the research were a strong support of understanding of the key players in BIM adoption. According to most of the intervieews the client is the one who is more interested in BIM, some of them referred more to the private client (Rig., 2014) (Cer., 2014) (Als., 2014) (Pen., 2014) (Pol., 2014), others see more the public client - the Governments - to have a key role of both interest and power (Cir., 2014) (Dol., 2014) (Pav., 2014). One of the intervieews in particular believed that the one gaining more benefits is the project manager, but the one with more power is still the client (Rad., 2014).

Once identified who the key stakeholders are, a natural wondering is about their practice. Regarding stakeholders' adoption, the major user in the building network resulted to be the architect, the adoption of engineers and contractors is comparable, the one of the owners is lower in respect to the previous one (Built Environment Innovation and Industry Council, 2010). Regarding the level of practice, BIM understanding and awareness resulted to be at BIM maturity level 


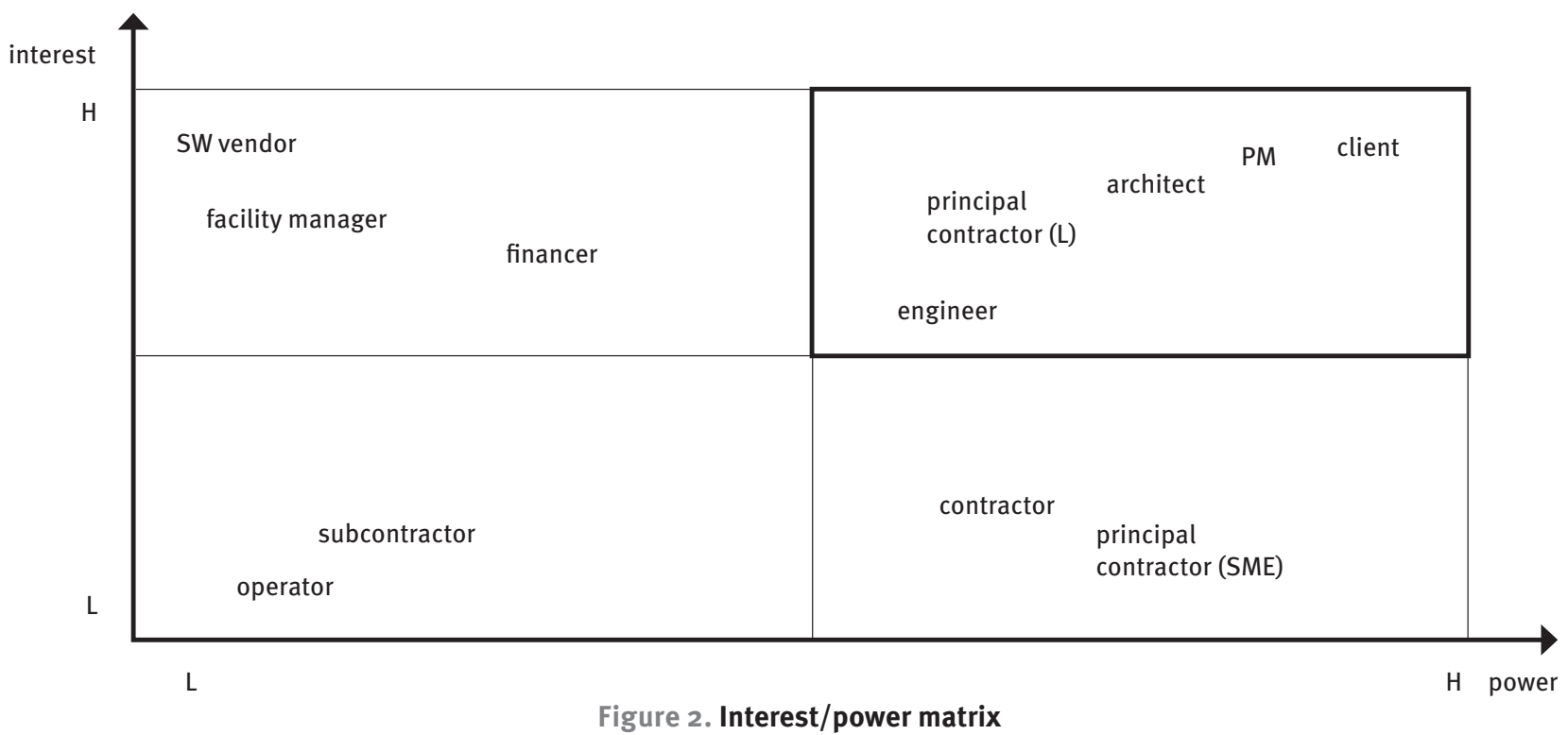

3 (a network-based integration BIM), the expectaction of overcoming current issues and problems by stakeholders is at level 2 (a model-based integration BIM), but BIM tool or system used/ seen used by stakeholders is still at level 1 (a object-based integration BIM), as for the services offered to the client thanks to the use of BIM, and the same also for the current vision of BIM implementation (Khosrowshahi \& Arayici, 2012) (Jones) (Majcherek, 2013). Finally regarding the differences of implementation in the construction subsectors, there is a significant inclination towards building, particularly real estate project. Instead the use of BIM is still low in the infrastructure and development domains (RICS, 2014).

The answer to the first research question is given through the adoption of the interest and power matrix, which takes into account only internal stakeholders. A further and important analysis need to be the one regarding the context and so the role of one of the external stakeholders: the Government, whose role leads the behaviour of the public sector. This second part aims to answer to the second research question: "What is the role of the Governments?". As already said, the focus is on the European countries.
European Governments BIM policy stage by adoption rating (see figure 3 ) is as follows. The Nordics - Finland and Norway - lead the way, the newcomers to BIM mandates are UK and Netherlands, and the countries yet to adopt the policy are Sweden, Denmark, Germany, France and Italy (Autodesk, 2013). Regarding the pioneers in BIM adoption, the first European country that mandated BIM was Finland in 2007, when its Senate required IFC (Industry Foundation Classes) BIM in its projects and explicitly intended to have integrated model-based operation - BIM level 2 - in the future. The adoption of BIM in Finland is further advanced than anywhere else in the world. Finland is a technologically advanced nation with a small, agile construction industry and a long history of trust and open standards, the perfect environment for BIM to thrive (ReCecconi, 2014). In Finland BIM is the standard for design, almost the $70 \%$ of the projects in the overall country are managed and developed with BIM tools, and the awareness reaches quite the $90 \%$ (NATSPEC, 2013). There are actions also from the private sectors driven by the Association of Finnish Contractors, and BIM programmes by research organizations and universities. In overall, public sector has been the key driver in BIM adoption and private companies have taken very few action compared to the Government. The other pioneer country is Norway whose Statbygg (civil state client) in 2010 required IFC BIM for new buildings and ran three BIM pilot projects. Its regulatory bodies and the construction industry all actively promoting the use of BIM have combined to make Norway a BIM success story. Norvegian biggest initiative is a new BIM standard for object libraries which has been recently released by Standards Norway (NATSPEC, 2013). So, the two leading countries have both required the use of $B I M$, in the Finnish case in all projects from 2007, and in the Norwegian one to be used for the whole life-cycle of buildings from 2010 (Wong, Wong, \& Nadeem, 2009).

To the newcomers belongs the most famous country connected to BIM: UK, mainly thanks to its effective marketing campaign. In May 2011, UK Government published the construction strategy aimed at reducing the cost of public sector assets by up to $20 \%$ by 2016 . The strategy calls "for a profound change in the relationship between public authorities and the construction industry to ensure the Government 


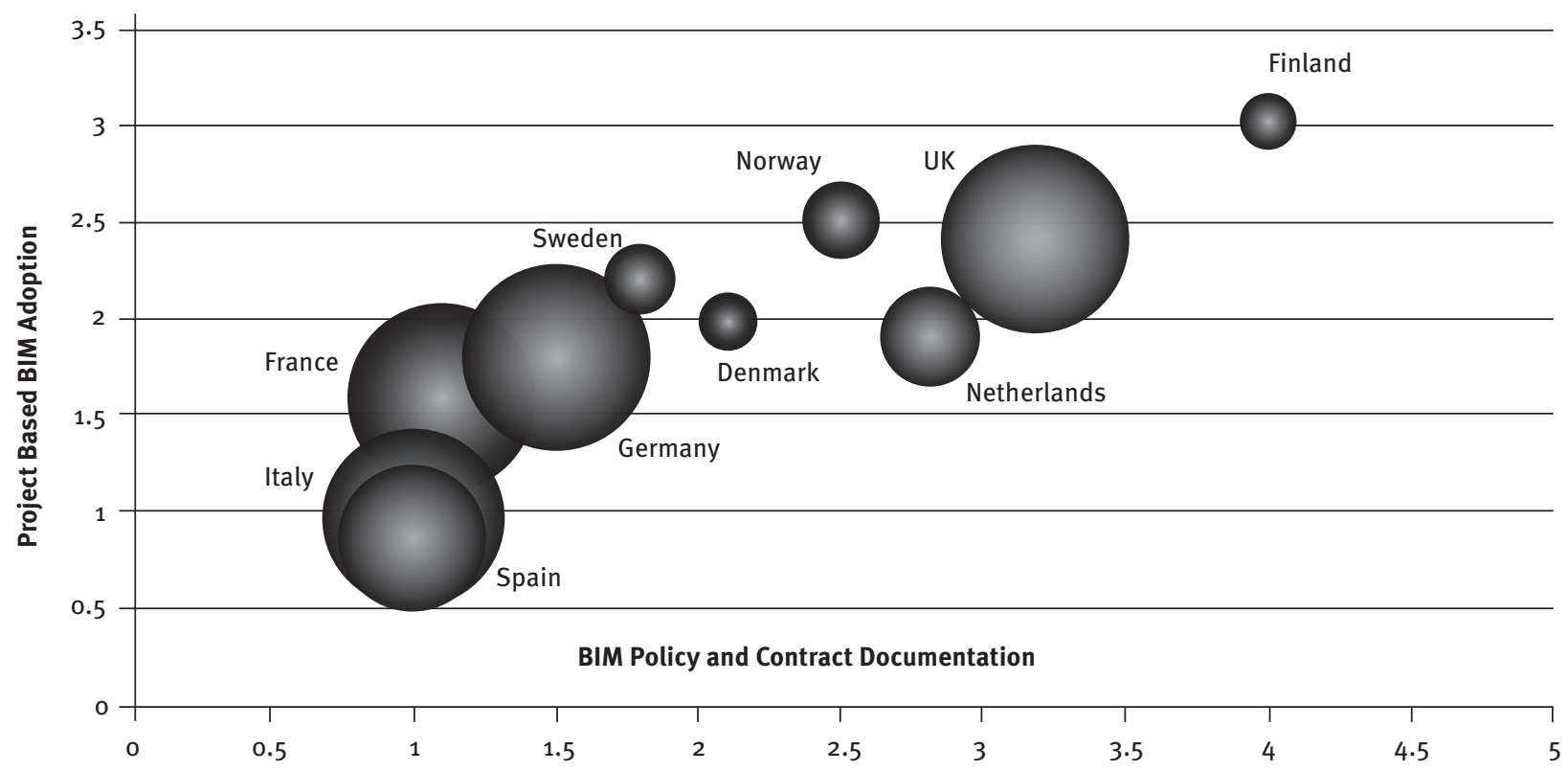

Figure 3. BIM policy stage by adoption rating - EU (Autodesk, 2013)

consistently gets a good deal and the country gets the social and economic infrastructure it needs for the longterm" (BIMTaskGroup). To achieve this strategy, the Government mandated that all companies tendering for Governmenta construction project should be working at BIM level 2 by 2016 (BIMTaskGroup). The obligation anyway is limited to England and Gales, and to central administration tenders and licences. UK Government has two distinctive objectives: first, forcing the supply - the operators to use obligatorily BIM method from 2016, UK's strategy in fact is towards market segment awareness; and second, giving a BIM literacy to all the operators, including the construction ones and the private demand (Cir., 2014). The Government/Industry BIM programme is focused on the adoption of BIM technology by both public and private sector organisations involved in the procurement and delivery of buildings and infrastructure. The Construction Industry Council (CIC) together with the Government put in place a number of industry focused programmes to assist the supply chain to gear up to Government's mandate of BIM at maturity level 2 by 2016 . Moreover UK translated his strategy into several actions and set detailed matrixes to be used by companies to plan a sequence of activities to ensure the English objective. Currently BIM adoption in UK is almost $40 \%$ and the awareness is more $90 \%$ (CasaeClima, 2014) (NATSPEC, 2013). English strong position can be explained with two possible reasons: first, BIM seems to be regarded as "life safer" for the future of the construction sector, and the public sector in Britain accounts for about $40 \%$ of construction sector investments, and especially the number of infrastructure projects is large; second, due to the strong hierarchical culture of the country, i.e. if the demand comes from a high enough source, it is not easily questioned, but generally accepted almost automatically (Kiviniemi, 2013). Regarding the other newcomer country - Netherlands -, its major initiatives are the CB-NL (Concept Library) project which has been initiated and the agreement reached with Building Smart International for a collaboration with BuildingSmart data dictionary (NATSPEC, 2013).
The European countries yet to adopt BIM are: Sweden, Denmark, Germany, France and Italy. Sweden is catching up with Finland and Norway and in particular in using BIM to design and build large and complex infrastructure projects, such as the Stockholm Bypass and the new City Line in Stockholm. Regarding Danish public sector and BIM guidelines, there are at least three public owners who have initiated the work on BIM. Denmark has actively put forth its requirements for using BIM in the Governmenta projects (NATSPEC, 2013). Also in Germany BIM is seen as an opportunity for its construction sector to grow. In fact the German BIM guide has been promoted by the Federal Institute for Building, Urban Affairs and Spatial Development, the Federal Ministry of Transport, Building and Urban Development, and by the Reform Commission construction of major projects. German market is moving with the realization of three pilot projects, and the digitalization of the business following the English example (Cir., 2014). Regarding France, two notable examples are given by establishment of the Infrastructure BIM Research National Program promoted 
by MEDDE (Ministère du Développement durable) and by the releases of the minister Cécile Duflot who affirmed the willingness and the French projects for the adoption and the diffusion of the technology in the construction sector. There are positive signs also from Italy. One important fact is the congress AICQ in Rome at the Superior Council for the public works, in January 2014: "BIM e il sistema delle costruzioni (trad. BIM and the construction system)". It was then followed by another one - ANCE congress - in Catania, in May. A further note about Italy need to be add regarding the INNOVance project, co-financed by the Ministry of the Economic Development. INNOVance is the project of the first national informative database platform in the construction sector (BIM, interoperable, open source) that was developed with the collaboration of all the supply chain stakeholder: from the project partners, to the UNI, going to the world of the designer (Pavan, 2014). The last important information to conclude the European overview regards the European Union. In January 2014 modifications in the European Union Public Procurement Directive (EUPPD) included the following important change: "for works contracts and design contests, Member States may require the use of specific electronic tools such as of building information electronic modelling tools or similar" (ReCecconi, 2014). The directive allows all EU member states to encourage, specify or mandate the use of BIM on publicly funded construction and building projects. The objective was not to mandate BIM but to let and encourage who was willing to impose it to do it without breaking any EU law.

\section{Conclusion}

This paper provides a clear insight of a stakeholder perspective on Building Information Modeling and project management. It managed to answer to two research questions: the first one regards the key stakeholder in BIM adoption - "Which kind of stakeholder is interested in BIM?" - and the second one regards the public situation in the different European countries - "What is the role of the Governments?". To answer to the first question the best point of view resulted to be the interest and power matrix which identifies who the key players in the construction sector are, regarding the adoption of BIM. They resulted to be, in ranking order: client, project manager, architect, principal contractor and engineer. The answer to the second research question is an overview of the European context. Leading, newcomers and yet to adopt countries are presented. Among the information provided, three considerations can be highlighted: first, the first country that mandated BIM was Finland in 2007 (7 years ago); second, the country which is the most famous regarding BIM is UK due to his commitment and positioning in Europe; third, a further step has been done also by the European Union who let the countries willing to mandate BIM free to do it. The research opens up to future developments due to its being a state of art of the stakeholder. Stakeholder management is full of dynamisms due both to stakeholders complex relationships and to the possible increasing of the awareness and the knowledge about the arguments, e.g. if the awareness of a one stakeholder about his benefits increases then his position in respect to the other changes. The context is a picture of the European situation and is even more prone to changes. In 5-10 years the scenarios of the role of the Governments will be totally different from now.

\section{References}

Als. (2014). Master thesis interview. (A. Travaglini, Interviewer)

Autodesk. (2013). BIM Adoption and Developments.

Baxter(Autodesk). (2013). BIM Adoption and Developments.

BIMTaskGroup. (n.d.). BIM task group. Retrieved from http://www.bimtaskgroup.org/

Browne, Odeyinka, McKeown, \& McNiff. (2013). BIM implementation throughout the UK construction project lifecycle: an analysis. Automation in construction.

Bryde, D., Broquetas, M., \& Volm, J. M. (2013). The project benefits of Building Information Modelling (BIM). International Journal of Project Management, 971-980.

BuiltEnvironmentInnovationandIndustryCouncil. (2010). Productivity in the buildings network: assessing the impacts of BIModels.

CasaeClima. (2014). BIM, chi lo usa in Europa? Retrieved from www.casaeclima.com

Cer. (2014). Master thesis interview.

(A. Travaglini, Interviewer)

Cir. (2014). Master thesis interview. (A. Travaglini, Interviewer)

Dol. (2014). Master thesis interview. (A. Travaglini, Interviewer)

Eastman, C., Teicholz, P., Sacks, R., \& Liston, K. (2008). BIM Handbook. A guide to building information modeling for owners, manager, designer, engineers and contractors. Wiley.

Evans. (2012). BIM: ready or not? NFB (National Federation of Builders).

Gu, \& London. (2010). Understanding and facilitating BIM adoption in the AEC industry. Automation in Construction.

Jianhua, C., \& Hui, W. (2010). Application and Popularizing of BIM Technology in Project Management.

Johnson, \& Scholes. (1999). Power/interest matrix.

Jones, G. (n.d.). Building a strategy for BIM: A Roadmap for Clients. AECOM.

Khosrowshahi, \& Arayici. (2012). Roadmap for implementation of BIM in theUKconstruction industry. Emerald.

Kiviniemi, A. (2013). ARTO KIVINIEMI: Introduction of BIM from the British perspective. Built Environment Innovations. 
Linderoth, H. (2012). Understanding adoption and use of BIM as the creation of actor networks. Automation in Construction.

Liu, Q., Gao, T., \& Wang, J. (2011). Research on Application of BIM Technology in Construction Project.

Majcherek, E. (2013). Building Information Modelling in the business of architecture.

Malone, A. (2014). BIM and the informed project manager.

McGrawHill. (2010). The business value of BIM in Europe: getting BIM to the bottom line in the UK, France and Germany.

Nash, Chinyio, Gameson, \& Suresh. (n.d.). The dynamism of stakeholders' power in construction projects.

NationalBIMStandard. (2014). National BIM Standard. Retrieved from http://www. nationalbimstandard.com/

NATSPEC. (2013). BIM educational.

NBS. (2013). BIM in UK today. NBS.

NBS. (2013). What is BIM?

Nemetschek-Allplan. (2014). Progettazione e costructione - dall'idea alla presentazione (Design and construction - from the idea to the presentation). Retrieved from http:// www.nemetschek-allplan.it/

NFB. (2012). BIM: ready or not? NFB.

Olander, S. (2006). External Stakeholder Analysis in Construction Project Management.

Pav. (2014). Master thesis interview. (A. Travaglini, Interviewer)

Pavan, A. (2014). BIM \& Construction Information Management. Il progetto INNOVance. Ingenio.
Pen. (2014). Master thesis interview.

(A. Travaglini, Interviewer)

PMI. (2008). Project management book of knowledge.

Pol. (2014). Master thesis interview. (A. Travaglini, Interviewer)

Rad. (2014). Master thesis interview.

(A. Travaglini, Interviewer)

ReCecconi, F. (2014). Rivoluzione BIM, l'errore che i progettisti non devono commettere. Maggioni editore.

RIB. (2009). Integrated building information modeling. Solution bried engineering, construction and operation.

RICS. (2014). State of BIM adoption and outlook in India.

Rig. (2014). Master thesis interview. (A. Travaglini, Interviewer)

Sebastian, R. (2011). Changing roles of the clients, architects and contractors through BIM. Emerald.

Succar, B. (2009). Building information modelling framework: A research and delivery foundation for industry stakeholders. Automation in construction.

Volk, Stenge, \& Schultmann. (2014). Building Information Modeling (BIM) for existing buildings, Literature review and future needs. Automation in Construction.

Wong, A., Wong, F., \& Nadeem, A. (2009). Comparative roles of major stakeholders for the implementation of BIM in various. Academia.

WSP. (2013). Retrieved from WSP: http://www. wspgroup.com/en/wsp-group-bim/BIMhome-wsp/what-is-bim/ 